\title{
JUDUL ARTIKEL PERAN INTERNET MARKETING DALAM MENINGKATKAN INTENTION TO BUY PADA KONSUMEN (Studi Kasus pada bangkayu.id)
}

\author{
Irsal Fauzi ${ }^{1}$ \\ D4 Bisnis dan Manajemen Ritel, Universitas Ngudi Waluyo \\ 1)irsalfauzi@unw.ac.id
}

\begin{abstract}
ABSTRAK
Internet marketing merupakan salah satu sarana penjualan yang paling efektif dan efisien, dan sedang mengalami trend kemajuan dalam penggunaannya. Banyak reseller atau dropshipper yang menggunakan internet marketing untuk menarik minat konsumennya untuk membeli. Begitu juga dengan bangkayu.id yang sudah lama menggunakan internet marketing di Instagram untuk meningkatkan penjualannya. Penelitian ini menggunakan kuesioner online yang dibagikan kepada 96 responden yang merupakan followers aktif akun @bangkayu.id. Hasil penelitian menggunakan Analisis Tabulasi Sederhana melalui pendekatan model AIDA untuk mengukur efektivitas periklanan @bangkayu.id. Hasil penelitian menunjukkan bahwa variabel Attention, produk @bangkayu.id mampu mengesankan dan efektif untuk menarik perhatian konsumen. Variabel interest menunjukkan bahwa "pesan" yang ingin ditampilkan pada produk @bangkayu.id efektif dalam menarik perhatian konsumen. Variabel Desire menunjukkan bahwa iklan di @bangkayu.id efektif dalam mempengaruhi persepsi konsumen dalam menggunakan produk. Variabel Action menunjukkan bahwa iklandi @bangkayu.id efektif dalam mempengaruhi konsumen untuk membeli produk@bangkayu.id.
\end{abstract}

Kata kunci: Internet marketing, Intention to buy, bangkayu.id.

\section{PENDAHULUAN}

Intensitas kegiatan sosial manusia membutuhkan media informasi dan komunikasi sebagai alat untuk mengekspresikan dan meng-ekspos kegiatannya, dan dengan adanya instagram menjadi salah satu jalan alternatif masyakarat modern sebagai media utama saat ini. Instagram memudahkan masyarakat terutama kaum muda untuk memenuhi aspek pengakuan dari orang lain dengan mem-posting aktivitas harian ataupun untuk mencari layanan produk serta jasa yang diinginkan. Pada tahun 2020, jumlah pengguna instagram di Indonesia menurut hasil survey yang dilakukan oleh Hootsuite (We are Social) berjumlah hingga 63 juta jiwa. Angka tersebut terdiri atas pengguna berjenis kelamin perempuasn sebesar $50,8 \%$ dan pengguna berjenis kelamin laki-laki seebesar 49,2\%. (https://andi.link/hootsuite-we-are-social-indonesian-digital-report-2020).

Maraknya penggunaan instagram dewasa ini mendorong banyaknya pelakupelaku usaha untuk melakukan kegiatan penjualan. Saat ini penjualan online (Internet marketing) merupakan sarana promosi yang efektif dan efisien, serta digunakan hampir seluruh pelaku usaha di seluruh dunia pada jaman perkembangan komunikasi pemasaran saat ini.

Salah satu variabel dalam bauran pemasaran ialah promosi. Kegiatan promosi bukan saja berfungsi sebagai alat komunikasi antara perusahaan dengan konsumen, 
melainkan juga sebagai alat untuk mempengaruhi konsumen dalam kegiatan pembelian atau penggunaan jasa sesuai dengan keinginan dan kebutuhannya (Lupiyoadi \& A.Hamdani, 2006). Promosi merupakan salah satu faktor penentu dalam keberhasilan suatu program pemasaran, karena promosi pada hakikatnya adalah suatu bentuk komunikasi pemasaran (Tjiptono, 2001). Banyak sekali alat promosi yang dapat digunakan. Akan tetapi, alat komunikasi paling efektif di instagram ialah dengan menggunakan iklan dalam bentuk foto dan video.

Iklan adalah bentuk komunikasi tidak langsung yang didasari pada informasi tentang keunggulan atau keuntungan suatu produk yang disusun sedemikian rupa sehingga menimbulkan rasa menyenangkan yang akan merubah pikiran seseorang untuk melakukan pembelian. Iklan merupakan salah satu bentuk promosi yang paling banyak digunakan perusahaan dalam mempromosikan produknya (Tjiptono, 2008). Penggunaan iklan diterapkan juaga oleh bangkayu.id dalam memperkenalkan dan meningkatkan volume penjualan produknya. bangkayu.id merupakan produk "rumah" yang dikhusukan untuk hewan peliharaan seperti kucing. Produk bangkayu.id dilengkapi dengan tali khusus yang nyaman agar kucing dapat mengasah kuku-kukunya dengan baik.

Iklan produk bangkayu.id harus bisa menyampaikan "pesan" yang hendak disampaikan pada konsumennya. Jika iklan tersebut tidak bisa menyampaikan "pesan" yang dimaksud maka besar kemungkinan iklan tersebut mendapat respon yang negatif, serta tidak akan mendatangkan niat beli (intention to buy) pada konsumennya. Periklanan terkadang menyita bagian yang besar dalam anggaran pemasaran dan seringkali merupakan bahan penting bagi keberhasilan suatu produk. Karenanya perusahaan harus berusaha menilai efektivitas suatu iklan dari pesan-pesan tertentu (sebelum atau selama implementasi program) dan efektivitas dari keseluruhan program periklanan dalam mencapai sasaran periklanan (Guiltinan \& Paul, 1994).

Penelitian mengenai promosi di instagram dilakukan oleh Ena Buinac (2016) yang mendapatkan hasil bahwa beberapa jenis gambar dan gaya lebih baik daripada yang lain mengenai penyebaran merek. Temuan ini juga menunjukkan bahwa aktivitas instagram memiliki pengaruh positif pada lalu lintas ke situs web web shop perusahaan. Penelitian ini didukung Hansel (2016) yang menunjukkan bahwa pemasaran melalui media sosial dapat memberikan dampak terhadap pendapatan perusahaan. Penelitian ini di dukung oleh Manneh (2017) yang menyatakan bahwa bahwa hampir semua perusahaan e-commerce mempekerjakan sosial media sebagai strategi pemasaran. Melalui analisis menyeluruh ditemukan bahwa Instagram adalah yang paling dominan dari semua platform media sosial. Penggunaan pemasaran media sosial sangat penting untuk e-commerce mode cepat bisnis ini, karena mereka dapat memiliki kontak langsung dengan pelanggan mereka, menarik pelanggan baru dan untuk mengenal mereka sasaran pasar. Kesemua perusahaan ini membuka bisnis e-commerce untuk menawarkan lembar data produk dan memperluas pasar untuk produk niche. Ashley (2015) mendukung bahwa pemasaran media sosial telah menjadi bentuk periklanan terbaru bagi perusahaan. Platform mobile social, Instagram, telah menjadi alat penting untuk pemasaran. Sekitar dua pertiga besar perusahaan sudah menggunakan Instagram untuk keuntungan mereka. Tidak ada pedoman pasti tentang caranya perusahaan harus beriklan sendiri di Instagram tetapi ada pola khusus yang bisa dikembangkan sebagai bagian dari bauran pemasaran.

Banyaknya toko online store yang telah merajai media sosial Instagram melalui fitur-fitur di dalamnya sebagai media pemasaran mereka, hal ini pula yang 
dimanfaatkan dengan baik oleh bangkayu.id dengan memberikan tampilan menarik di akun miliknya yaitu dengan cara mengunggah foto yang selalu berwarna-warni disertai tulisan-tulisan yang menarik, dan gambar-gambar disetiap foto katalog produknya. Maka dari itu, hal inilah yang mendasari bisnis bangkayu.id untuk membuat konsumen tidak hanya puas dengan produknya, akan tetapi juga dengan konten unggahan produknya di instagram.

Penelitian ini mencoba untuk menganalisis efektivitas iklan pada produk bangkayu.id melalui metode AIDA (Attention, Interest, Desire, Action), sehingga judul pada penelitian ini ialah "Peran Internet Marketing Dalam Meningkatkan Intention to Buy Pada Konsumen (Studi Kasus Pada produk bangkayu,id.)."

\section{LANDASAN TEORI}

\section{Teori Komunikasi Pemasaran}

Dasar dari pemasaran adalah komunikasi dan pemasaran bisa akan begitu powerful jika dipadukan dengan komunikasi yang efektif dan efisien. Bagaimana menarik konsumen atau khalayak menjadi aware, kenal dan mau membeli suatu produk atau jasa melalui saluran komunikasi adalah bukan sesuatu yang mudah.

Menurut Koetler dan Keller, "marketing communications are the means by which firm attempts to inform, persuade, and remind consumers-directly or indirectly about the product and brand they sell". (Komunikasi pemasaran merupakan sarana bagi perusahaan untuk menginformasikan, membujuk, dan mengingatkan konsumen baik secara langsung atau tidak langsung tentang produk dan merek yang mereka jual). Hal ini berarti, komunikasi pemasaran mewakili "suara" dari perusahaan dan merek perusahaan serta sarana yang dapat membangun dialog dan juga membangun hubungan dengan konsumen (Kotler, 2009).

Hubungan antara pemasaran dengan komunikasi merupakan hubungan yang erat. Komunikasi merupakan proses dimana pemikiran dan pemahaman disampaikan antar individu, atau antara perusahaan dan individu. Komunikasi dalam kegiatan pemasaran bersifat kompleks, tidak sesederhana seperti berbincang-bincang dengan teman atau keluarga. Bentuk komunikasi yang lebih rumit akan mendorong penyampaian pesan oleh komunikator pada komunikan, melalui strategi komunikasi yang tepat dengan proses perencanaan yang matang.

Definisi lain menunjukkan komunikasi menurut Hovland, Janis dan Kelley yang berbunyi, "Communication is the process by which an individual transmits stimuly (usually verbal) to modify the behaviour of the other individuals". (Komunikasi adalah proses individu mengirim stimulus yang biasanya dalam bentuk verbal untuk mengubah tingkah laku orang lain). Definisi tersebut mengimplikasikan bahwa komunikasi adalah suatu proses sosial yang terjadi antara sedikitnya dua orang, dimana individu mengirim stimulus kepada orang lain. Stimulus dapat disebut sebagai pesan yang biasanya dalam bentuk verbal, dimana proses penyampaian dilakukan melalui saluran komunikasi, dan terjadi perubahan atau respons terhadap pesan yang disampaikan.

Secara teoritis dan praktis, aktivitas promosi dapat dikatakan sebagai bagian dari komunikasi pemasaran. Komunikasi pemasaran adalah bagian dari aktivitas keseluruhan pemasaran. Pemasaran sendiri banyak didefinisikan oleh para ahli. Menurut Koetler and Keller "marketing is a social process by which individuals and groups obtain what they need and want throught creating offering, and freely exchanging product and services of value with others". (Pemasaran adalah proses sosial dimana individu-individu dan 
kelompok memperoleh apa yang mereka butuhkan dan inginkan melalui penciptaan dan pertukaran poduk dan penilaian pelayanan dari orang lain). (Kotler, 2009).

Jika digabungkan, komunikasi pemasaran merepresentasikan gabungan semua elemen dalam bauran pemasaran, yang memfasilitasi pertukaran dengan menargetkan merek untuk sekelompok pelanggan, posisi merek yang membedakan dengan merek pesaing dengan menciptakan suatu arti yang disebarluaskan kepada pelanggannya.

Penggabungan kajian pemasaran dan komunikasi akan menghasilkan kajian baru yang disebut marketing communication (komunikasi pemasaran). Marketing communications merupakan bentuk komunikasi yang bertujuan untuk memperkuat strategi pemasaran, guna meraih segmen pasar yang lebih luas. Perusahaan menggunakan berbagai bentuk komunikasi pemasaran untuk mempromosikan apa yang mereka tawarkan dan mencapai tujuan finansial. Kegiatan pemasaran yang melibatkan aktivitas komunikasi meliputi iklan, tenaga penjualan, papan nama toko, display ditempat pembelian, kemasan produk, direct-mail, sampel produk gratis, kupon, publisitas, dan alat-alat komunikasi lainnya. Secara keseluruhan, aktivitas-aktivitas tersebut diatas merupakan komponen promosi dalam bauran pemasaran (marketing mix). (Shimp, 2003). Komunikasi pemasaran tersebut dapat dikelompokkan menjadi empat komponen pemasaran yang terdiri dari 4P, yakni : product (produk), Price (harga), Place (tempat, termasuk juga distribusi), dan promotion (promosi) dan jenis-jenis model komponen pemasaran meliputi iklan (advertising), Promosi Penjualan (Sales Promotion), Hubungan Masyarakat (Public Relation) dan Penjualan Perorangan (Personal Selling) (Kennedy dan Soemanagara, 2006).

\section{Pengukuran Efektivitas Iklan Model AIDA}

Untuk melakukan promosi, perusahaan harus merancang atau mendesain pesanpesan menjadi efektif. Idealnya, pesan harus mendapat perhatian (Attention), mempertahankan minat (Interest), membangkitkan hasrat (Desire), dan meraih tindakan (Action) (kerangka kerja dikenal sebagai model AIDA). Banyak dari yang kita temukan bahwa hanya sedikit pesan yang membawa konsumen dari kesadaran sampai pembelian, tetapi kerangka kerja AIDA menyarankan kualitas pesan baik yang diinginkan (Kotler dan Armstrong, 2008).

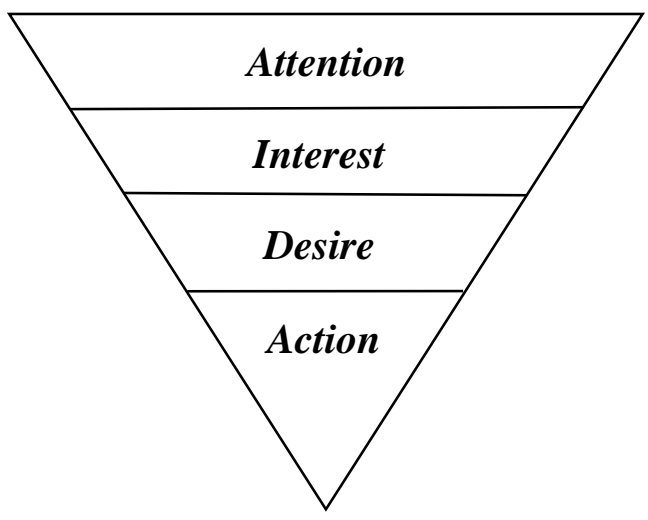

Gambar 1. Model AIDA

Sumber : Kotler \& Armstrong (2008) 


\section{MODEL PENELITIAN}

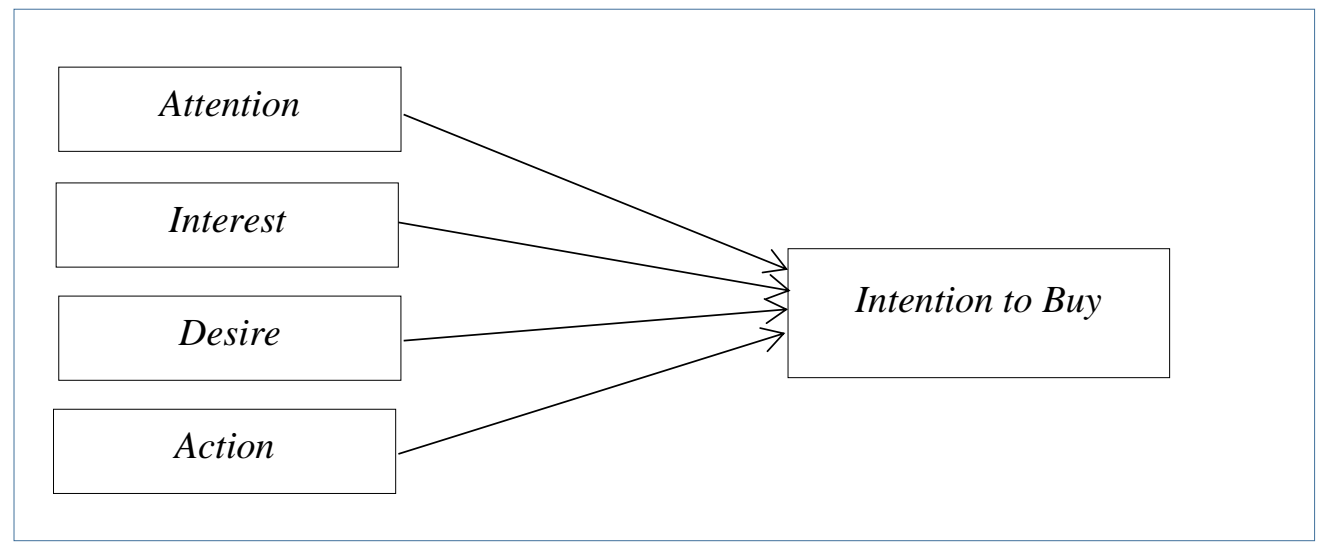

Gambar 2. Model Penelitian

\section{METODE PENELITIAN}

\section{Jenis Penelitian}

Dalam penelitian ini menggunakan metode penelitian deskriptif dengan pendekatan kuantitatif. Menurut Sugiyono (2009) metode penelitian kuantitatif berlandaskan pada filsafat positivism, digunakan untuk meneliti pada populasi atau sampel tertentu, pengumpulan data menggunakan instrument penelitian, analisis data bersifat statistik. Lebih lanjut Sugiyono (2009) menjelaskan penelitian deskriptif yaitu, penelitian yang dilakukan untuk mengetahui nilai variabel mandiri, baik satu variabel atau lebih tanpa membuat perbandingan atau menghubungkan dengan variable lain.

\section{Sumber Data}

Sumber data yang digunakan dalam penelitian ini adalah data primer yaotu menggunakan kuesioner online yang dibagikan kepada responden bangkayu.id.

\section{Populasi dan Sampel}

Dalam penelitian ini populasinya adalah seluruh pengikut yang ada dalam akun bangkayu.id pada media sosial Instagram (@bangkayu.id. Karena jumlah pengikut pada akun tersebut selalu bertambah maka peneliti tidak mendapatkan data yang valid. Maka dari itu ukuran populasi dalam penelitian ini tidak terhingga.

Teknik pengambilan sampel pada penelitian ini menggunakan teknik non propbability. Peneliti Menggunakan non probability sampling karena tidak memberikan peluang yang sama untuk menjadi anggota sampel. Berdasarkan non probability sampling teknik yang digunakan dalam penelitian ini adalah accidental sampling. Teknik sampling insidental yakni penentuan sampel berdasarkan kebetulan, yaitu siapa saja yang secara kebetulan/insidental bertemu dengan peneliti dapat digunakan sebagai sampel, bila dipandang orang yang kebetulan ditemui itu cocok sebagai sumber data (Sugiyono, $2012: 56$ ).

Jumlah sampel yang diambil dalam penelitian ini menggunakan rumus Lemeshow, hal ini dikarenakan jumlah populasi yang tidak diketahui atau tidak terhingga. 


\section{Definisi Konsep}

Definisi konsepsional adalah pemaknaan atau pemberian definisi dari konsep yang digunakan. Konseptualisasi dapat juga dikatakan sebagai proses yang digunakan untuk menunjukkan secara tepat tentang apa yang kita maksudkan bila kita menggunakan suatu istilah tertentu (Priyono, $2016: 79$ ).

Menurut Wijaya (2011) dalam Johar, Kumadji, dan Mawardi (2015) salah atu model yang sering digunakan untuk mengetahui pengaruh iklan terhadap perilaku konsumen adalah model AIDA. Model AIDA adalah model yang menjelaskan langkah - langkah yang dilakukan konsumen dalam merespon iklan, langkah tersebut meliputi : attention (perhatian), interest (minat), desire (kemauan), dan action (tindakan pembelian produk atau jasa).

1) Attention yaitu tahap dimana konsumen memberi perhatian pada iklan

2) Interest yaitu tahap dimana konsumen menjadi tertarik pada iklan.

3) Desire tahap dimana konsumen berkeinginan terhadap merek atau produk setelah mendapatkan informasi tentang merek atau informasi tentang merek atau informasi tambahan sehubungan dengan pesan iklan.

4) Action yang mana konsumen melakukan tindakan berupa pembelian produk atau pemilihan merek untuk memuaskan keinginannya.

\section{Definisi Operasional Konsep}

Metode penelitian menggambarkan jenis dan sumber data, populasi dan sampel, definisi konsep, definisi operasional konsep, teknik analisis data jika menggunakan data kuantitatif. Sedangkan untuk penelitian kualitatif dijelaskan bagaimana proses dari perolehan data penelitian.

Definisi Operasional merupakan gambaran teliti mengenai prosedur yang diperlukan untuk memasukkan unit-unit analisis ke dalam kategori-kategori tertentu dari tiaptiap variabel (Priyono, $2016: 79)$.

\section{1) Attention}

Tindakan ketertarikan calon pembeli terhadap produk iklan produk bangkayu.id Indonesia di media sosial Instagram. Indikator Attention :

1. Pesan yang disampaikan dalam iklan.

2. Visualisasi iklan yang menarik.

3. Intensitas iklan

\section{2) Interest}

Tahap Dimana calon pembeli memberi persepsi terhadap produk kosmetik wardah setelah melihat iklan produk pakaian bangkayu.id di media sosial Instagram. Interest terdiri dari tiga indikator :

1. Efektifitas media yang digunakan.

2. Persepsi konsumen mengenai produk setelah iklan ditampilkan.

3. Kejelasan pesan.

\section{3) Desire}

Tahap calon konsumen tertarik terhadap produk kosmetik wardah setelah mendapat informasi dari iklan produk pakaian bangkayu.id dari Instagram dan berminat memiliki produk atas dasar kebutuhan. Desire terdiri dari tiga indikator :

1. Perolehan informasi dari iklan.

2. Minat konsumen atas iklan.

3. Kepercayaan konsumen akan produk. 


\section{4) Action}

Pada tahap ini calon konsumen membuat keputusan untuk melakukan pembelian produk produk pakaian Bangkayu.id. Action terdiri dari tiga indikator :

1. Keyakinan untuk membeli produk.

2. Iklan menggunakan kata - kata yang sopan dan elegan.

3. Iklan diskon yang berkali-kali.

\section{Teknik Analisis Data}

Statistik Deskriptif adalah statistik yang digunakan untuk menganalisis data dengan cara mendeskripsikan atau menggambarkan data yang terkumpul menggenai tanggapan responden. Pada penelitian ini, analis statistik deskriptif akan menganalisis gambaran terhadap Efektifitas Iklan produk bangkayu.id menggunakan analisis tabulasi sederhana.

Dalam analisis deskriptif (Durianto, 2003 : 95), data yang diperoleh kemudian diolah dengan rumus :

$$
\mathrm{P}=\frac{f i}{\sum f i} \times 100 \%
$$

Keterangan :

$\mathrm{P} \quad$ : $\quad$ Presentase responden yang memilih kategori tertentu.

fi : Jumlah responden yang memilih kategori tertentu.

¿fi : $\quad$ Banyaknya jumlah responden.

Penggunaan rumus analisis tabulasi sederhana akan memepermudah dalam mengetahui frekuensi dari jumlah responden yang memilih kategori tertentu dan didapatkan prosentase responden yang memilih kategori tersebut. Skor jawaban yang diberikan responden diberi bobot. Cara menghitung skor adalah dengan menjumlahkan seluruh hasil kali nilai masing-masing bobotnya dibagi dengan total frekuensi (Durianto 2003 : 97). Rumus perhitungannya sebagai berikut:

$$
x=\frac{\sum f i . w i}{\sum f i}
$$

Keterangan :

$\begin{array}{lll}\text { x } & : & \text { Rata-rata berbobot } \\ \text { fi } & : & \text { Frekuensi } \\ \text { wi } & : & \text { Bobot }\end{array}$

Rumus diatas dipergunakan untuk mengetahui rata-rata berbobot yang diketahui dari hasil pembanding antara frekuensi dan bobot. Setelah itu, digunakan rentang skala penilaian untuk menentukan posisi tanggapan responden dengan menggunakan skor setiap variabel. Bobot alternatif yang terbentuk dari teknik skala peringkat terdiri dari kisaran antara 1 sampai 5 yang menggambarkan posisi yang sangat negatif ke posisi positif. Selanjutnya, dihitung rentang skala dengan rumus sebagai berikut:

$$
R s=\frac{R(\text { bobot })}{M}
$$

Keterangan :

$\begin{array}{lll}\mathrm{R} \text { (bobot) } & : & \text { Bobot terbesar }- \text { bobot terkecil } \\ \mathrm{M} & : & \text { Banyaknya kategori bobot }\end{array}$




\section{HASIL DAN PEMBAHASAN}

\section{Hasil}

\section{1) Attention}

Tabel 1 : Variabel Attention 1

Visualisasi iklan produk bangkayu.id

\begin{tabular}{|c|c|c|c|c|}
\hline \multirow[b]{2}{*}{$\begin{array}{l}\text { Indikator } \\
\text { Penilaian }\end{array}$} & \multirow[b]{2}{*}{$\begin{array}{c}\text { Bobot } \\
\text { (wi) }\end{array}$} & \multicolumn{3}{|c|}{ Attention 1} \\
\hline & & $\begin{array}{c}\text { Frekuensi } \\
\text { (Fi) }\end{array}$ & Presentase \% & $\begin{array}{c}\Sigma \\
\text { (wi.F) }\end{array}$ \\
\hline Sangat tidak Setuju & 1 & 4 & 4,2 & 4 \\
\hline Tidak Setuju & 2 & 6 & 6,3 & 12 \\
\hline Cukup Setuju & 3 & 9 & 9,4 & 27 \\
\hline Setuju & 4 & 55 & 57,3 & 220 \\
\hline Sangat Setuju & 5 & 22 & 22,9 & 110 \\
\hline \multirow[t]{2}{*}{ Total } & & 9 & 100 & 373 \\
\hline & \multicolumn{3}{|c|}{ Rata-rata Item } & 3,88 \\
\hline
\end{tabular}

Source: Primary data processed, 2021

Rata-rata variabel attention 1 sebesar 3,88 yaitu pada kategori "Efektif" dan dapat diartikan bahwa visualisasi dalam tayangan iklan produk @bangkayu.id pada media sosial Instagram efektif untuk menarik perhatian responden dilihat dari aspek attention. Produk@bangkayu.id merupakan salah satu bisnis online di media sosial yang memasarkan produk rumah kucing lokal dengan buatan tangan sendiri yang saat ini sedang berkembang, maka tidak heran apabila @bangkayu.id sangat memperhatikan visualisasi dari iklannya agar diketahui oleh calon konsumen.

Tabel 2 : Variabel Attention 2

Intensitas iklan produk @ bangkayu.id

\begin{tabular}{lcccc}
\hline \multirow{2}{*}{$\begin{array}{l}\text { Indikator } \\
\text { Penilaian }\end{array}$} & \multirow{2}{*}{$\begin{array}{c}\text { Bobot } \\
\text { (wi) }\end{array}$} & $\begin{array}{c}\text { Frekuensi } \\
\text { (Fi) }\end{array}$ & Presentase $\%$ & $\begin{array}{c}\boldsymbol{\Sigma} \\
\text { (wi.F) }\end{array}$ \\
\cline { 3 - 5 } Sangat tidak Setuju & 1 & 3 & 3,1 & 3 \\
Tidak Setuju & 2 & 4 & 4,2 & 8 \\
Cukup Setuju & 3 & 8 & 8,3 & 24 \\
Setuju & 4 & 52 & 54,2 & 208 \\
Sangat Setuju & 5 & 29 & 30,2 & 145 \\
\hline \multicolumn{1}{c}{ Total } & $\mathbf{9 6}$ & $\mathbf{1 0 0}$ & $\mathbf{3 8 8}$ \\
\hline \multicolumn{5}{r}{} \\
\hline
\end{tabular}

Source: Primary data processed, 2021

Rata-rata variabel attention 2 sebesar 4,04 yaitu pada kategori "Efektif" dan dapat diartikan bahwa intensitas iklan pada produk @ bangkayu.id di media sosial Instagram efektif untuk menarik perhatian dan berhasil membuat responden tertarik untuk menggunakan produk @bangkayu.id. Seringnya iklan produk @bangkayu.id muncul di Instagram secara bawah sadar berhasil menghipnotis responden untuk selalu mengingat @bangkayu.id sebagai produsen rumah kucing lokal berkualitas dengan harga terjangkau, serta iklannya mudah dicari di media sosial Instagram. 
Tabel 3 : Variabel Attention 3

Pesan iklan produk@bangkayu.id

\begin{tabular}{|c|c|c|c|c|}
\hline \multirow[b]{2}{*}{$\begin{array}{l}\text { Indikator } \\
\text { Penilaian }\end{array}$} & \multirow[b]{2}{*}{$\begin{array}{l}\text { Bobot } \\
\text { (wi) }\end{array}$} & \multicolumn{3}{|c|}{ Attention 3} \\
\hline & & $\begin{array}{c}\text { Frekuensi } \\
\text { (Fi) }\end{array}$ & Presentase \% & $\underset{\text { (wi.F) }}{\Sigma}$ \\
\hline Sangat tidak Setuju & 1 & 3 & 3,1 & 3 \\
\hline Tidak Setuju & 2 & 5 & 5,2 & 10 \\
\hline Cukup Setuju & 3 & 4 & 4,2 & 12 \\
\hline Setuju & 4 & 52 & 54,2 & 208 \\
\hline Sangat Setuju & 5 & 32 & 33,3 & 160 \\
\hline Total & & 96 & 100 & 393 \\
\hline \multicolumn{4}{|c|}{ Rata-rata Item } & 4,09 \\
\hline
\end{tabular}

Source: Primary data processed, 2021

Rata-rata variabel attention 3 sebesar 4,09 yaitu pada kategori "Efektif". Setiap iklan yang ditayangkan pasti memiliki tujuan dan pesan yang diberikan kepada audiens, begitu pula dengan iklan pada produk @ bangkayu.id di media sosial Instagram. Hal ini bertujuan sebagai pengenalan dan penguatan merek @bangkayu.id sebagai produsen rumah kucing lokal berkualitas dengan harga terjangkau, serta iklannya mudah dicari di media sosial Instagram.

Tabulasi sederhana pada butir pertanyaan Attention 1,2,3 jawaban responden cenderung dengan jawaban pada atribut "Setuju" dan pada kategori efektif. Setelah ketiga pertanyaan Attention keseluruhan dijumlahkan langkah selanjutnya yaitu menghitung rata-rata dari keseluruhan tahap attention untuk mengetahui tingkat efektifnya.

Analisis rata-rata dari keseluruhan variabel attemtion 1, 2, 3. Dimaksudkan untuk mengetahui keefektifannya. Maka perhitungannya menggunaakan rumus sebagai berikut:

$$
\begin{aligned}
& \begin{aligned}
x & =\frac{\sum f i . w i}{\sum f i}
\end{aligned} \\
& \text { x : Rata-rata berbobot } \\
& \text { fi : Frekuensi } \\
& \text { wi : Bobot }
\end{aligned}
$$

Nilai Rata - rata dari variabel Attention $1: 3,88$

Nilai Rata - rata dari variabel Attention $2: 4,04$

Nilai Rata - rata dari variabel Attention $3: 4,09$

Dengan demikian didapat hasil sebagai berikut:

$$
\frac{3,88+4,04+4,09}{3}=4,00
$$

Dari perhitungan tersebut nilai Attention (Perhatian) adalah sebesar 4,00 nilai ini berada pada rentang skala 3,40 - 4,19 yaitu "Efektif" Dapat disimpulkan bahwa pada tahap attention iklan produk @bangkayu.id pada media sosial Instagram efektif membuat audiens menaruh perhatian saat iklan@bangkayu.id muncul pada media sosial Instagram. 


\section{2) Interest}

Tabel 4 : Variabel Interest 1

Visualisasi iklan produk @bangkayu.id

\begin{tabular}{lcccc}
\hline \multirow{2}{*}{$\begin{array}{c}\text { Indikator } \\
\text { Penilaian }\end{array}$} & $\begin{array}{c}\text { Bobot } \\
\text { (wi) }\end{array}$ & $\begin{array}{c}\text { Frekuensi } \\
\text { (Fi) }\end{array}$ & Presentase $\%$ & $\begin{array}{c}\mathbf{\Sigma} \\
\text { (wi.F) }\end{array}$ \\
\cline { 3 - 5 } Sangat tidak Setuju & 1 & 3 & 3,1 & 3 \\
Tidak Setuju & 2 & 4 & 4,2 & 8 \\
Cukup Setuju & 3 & 5 & 5,2 & 15 \\
Setuju & 4 & 72 & 75 & 288 \\
Sangat Setuju & 5 & 12 & 12,5 & 60 \\
\hline \multicolumn{1}{c}{ Total } & $\mathbf{9 6}$ & $\mathbf{1 0 0}$ & $\mathbf{3 7 4}$ \\
\hline & \multicolumn{2}{c}{ Rata-rata Item } \\
\hline
\end{tabular}

Source: Primary data processed, 2021

Rata-rata variabel interest 1 sebesar 3,89 yaitu pada kategori "Efektif" dan dapat diartikan bahwa visualisasi pesan dalam tayangan iklan produk @bangkayu.id pada media sosial Instagram efektif untuk menarik perhatian responden. Pengunaan visualisasi yang tepat seperti musik, pencahayaan, warna, dan gambar membuat produk iklan@bangkayu.id nampak berbeda dengan produk iklan lainnya. Hal ini membuat calon konsumen merasa tertarik terhadap produk @ bangkayu.id.

Tabel 5 : Variabel Interest 2

Stimulus iklan produk @ bangkayu.id

\begin{tabular}{|c|c|c|c|c|}
\hline \multirow{2}{*}{$\begin{array}{l}\text { Indikator } \\
\text { Penilaian }\end{array}$} & \multirow[b]{2}{*}{$\begin{array}{c}\text { Bobot } \\
\text { (wi) }\end{array}$} & \multicolumn{3}{|c|}{ Interest 2} \\
\hline & & $\begin{array}{c}\text { Frekuensi } \\
(\mathbf{F i})\end{array}$ & Presentase \% & $\begin{array}{c}\Sigma \\
\text { (wi.F) }\end{array}$ \\
\hline Sangat tidak Setuju & 1 & 2 & 2,1 & 2 \\
\hline Tidak Setuju & 2 & 3 & 3,1 & 6 \\
\hline Cukup Setuju & 3 & 6 & 6,3 & 18 \\
\hline Setuju & 4 & 52 & 54,2 & 208 \\
\hline Sangat Setuju & 5 & 33 & 34,4 & 165 \\
\hline Total & & 96 & 100 & 399 \\
\hline \multicolumn{4}{|c|}{ Rata-rata Item } & 4,16 \\
\hline
\end{tabular}

Source: Primary data processed, 2021

Rata-rata variabel interest 2 sebesar 4,16 yaitu pada kategori "Efektif. Sangat penting bagi @bangkayu.id untuk memperhatikan bentuk stimulus yang akan dirancang. Salah satu cara untuk menumbuhkan ketertarikan audiens terhadap iklan di media sosial Instagram pada produk @bangkayu.id yaitu dengan cara mengadakan give away maupun diskon, dengan begitu audiens pasti akan lebih tertarik untuk mengetahui lebih dalam tentang iklan produk @ bangkayu.id.

Tabel 6 : Variabel Interest 3

Pesan iklan produk @ bangkayu.id

\begin{tabular}{|c|c|c|c|c|}
\hline \multirow[b]{2}{*}{$\begin{array}{l}\text { Indikator } \\
\text { Penilaian }\end{array}$} & \multirow[b]{2}{*}{$\begin{array}{c}\text { Bobot } \\
\text { (wi) }\end{array}$} & \multicolumn{3}{|c|}{ Interest 2} \\
\hline & & $\begin{array}{l}\text { Frekuensi } \\
\text { (Fi) }\end{array}$ & Presentase \% & $\begin{array}{c}\Sigma \\
\text { (wi.F) }\end{array}$ \\
\hline Sangat tidak Setuju & 1 & 2 & 2,1 & 2 \\
\hline Tidak Setuju & 2 & 3 & 3,1 & 6 \\
\hline Cukup Setuju & 3 & 2 & 2,1 & 6 \\
\hline Setuju & 4 & 67 & 69,8 & 268 \\
\hline Sangat Setuju & 5 & 22 & 22,9 & 110 \\
\hline Total & & 96 & 100 & 392 \\
\hline \multicolumn{4}{|c|}{ Rata-rata Item } & 4,08 \\
\hline
\end{tabular}

Source: Primary data processed, 2021 
Rata-rata variabel interest 3 sebesar 4,08 yaitu pada kategori "Efektif. Sangat penting bagi @bangkayu.id untuk memperhatikan bentuk pesan yang akan disampaikan pada audiens. Salah satu cara untuk menumbuhkan ketertarikan audiens terhadap iklan di media sosial Instagram pada produk @bangkayu.id yaitu dengan cara setiap iklan @bangkayu.id harus dapat menciptakan emosi positif. Iklan transformasional biasanya dapat mempengaruhi emosi dan perasaan konsumen secara efektif, dengan menunjukkan pengalaman menggunakan produk berdasarkan emosi.

Tabulasi sederhana pada butir pertanyaan Interest 1,2,3 jawaban responden cenderung dengan jawaban pada atribut "Setuju" dan pada kategori efektif. Setelah ketiga pertanyaan Interest keseluruhan dijumlahkan langkah selanjutnya yaitu menghitung rata-rata dari keseluruhan tahap attention untuk mengetahui tingkat efektifnya.

Analisis rata-rata dari keseluruhan variabel interest 1, 2, 3. Dimaksudkan untuk mengetahui keefektifannya. Maka perhitungannya menggunaakan rumus sebagai berikut:

Keterangan :

$$
x=\frac{\sum f i . w i}{\sum f i}
$$

$\begin{array}{lll}\mathrm{x} & : & \text { Rata-rata berbobot } \\ \text { fi } & : & \text { Frekuensi } \\ \text { wi } & : & \text { Bobot }\end{array}$

Nilai Rata - rata dari variabel Interest $1: 3,89$

Nilai Rata - rata dari variabel Interest $2: 4,16$

Nilai Rata - rata dari variabel Interest $3: 4,08$

Dengan demikian didapat hasil sebagai berikut:

$$
\frac{3,89+4,16+4,08}{3}=4,04
$$

Dari perhitungan tersebut nilai Interest (Ketertarikan) adalah sebesar 4,04 nilai ini berada pada rentang skala 3,40 - 4,20 yaitu "Efektif" Dapat disimpulkan bahwa pada tahap interest iklan produk @ bangkayu.id pada media sosial Instagram efektif membuat audiens merasa tertarik saat iklan @ bangkayu.id muncul pada media sosial Instagram.

\section{3) Desire}

Tabel 7 : Variabel Desire 1

\begin{tabular}{|c|c|c|c|c|}
\hline \multirow[b]{2}{*}{$\begin{array}{l}\text { Indikator } \\
\text { Penilaian }\end{array}$} & \multirow[b]{2}{*}{$\begin{array}{c}\text { Bobot } \\
\text { (wi) }\end{array}$} & \multicolumn{3}{|c|}{ Desire 1} \\
\hline & & $\begin{array}{l}\text { Frekuensi } \\
\text { (Fi) }\end{array}$ & Presentase \% & $\underset{\text { (wi.F) }}{\Sigma}$ \\
\hline Sangat tidak Setuju & 1 & 2 & 2,1 & 2 \\
\hline Tidak Setuju & 2 & 2 & 2,1 & 4 \\
\hline Cukup Setuju & 3 & 10 & 10,4 & 30 \\
\hline Setuju & 4 & 58 & 60,4 & 232 \\
\hline Sangat Setuju & 5 & 24 & 25 & 120 \\
\hline Total & & 96 & 100 & 388 \\
\hline \multicolumn{4}{|c|}{ Rata-rata Item } & 4,04 \\
\hline
\end{tabular}

Informasi mengenai produk @ bangkayu.id

Rata-rata variabel desire 1 sebesar 4,04 yaitu pada kategori "Efektif" dan dapat 
diartikan iklan produk @bangkayu.id pada media sosial Instagram efektif dalam mempengaruhi, responden memiliki keinginan untuk menggunakan produk yang diiklankan. Menumbuhkan kepercayaan responden dengan iklan pada media massa merupakan hal yang sulit, akan tetapi hal ini dapat disiasati dengan memberikan kejelasan informasi yang jelas dan mudah dipahami oleh para konsumen.

Tabel 8 : Variabel Desire 2

Informasi mengenai produk @ bangkayu.id

\begin{tabular}{|c|c|c|c|c|}
\hline \multirow{2}{*}{$\begin{array}{l}\text { Indikator } \\
\text { Penilaian }\end{array}$} & \multirow{2}{*}{$\begin{array}{c}\text { Bobot } \\
\text { (wi) }\end{array}$} & \multicolumn{3}{|c|}{ Desire 2} \\
\hline & & $\begin{array}{l}\text { Frekuensi } \\
\text { (Fi) }\end{array}$ & Presentase \% & $\begin{array}{c}\Sigma \\
\text { (wi.F) }\end{array}$ \\
\hline Sangat tidak Setuju & 1 & 2 & 2,1 & 2 \\
\hline Tidak Setuju & 2 & 3 & 3,1 & 6 \\
\hline Cukup Setuju & 3 & 1 & 1 & 3 \\
\hline Setuju & 4 & 52 & 54,2 & 208 \\
\hline Sangat Setuju & 5 & 38 & 39,6 & 190 \\
\hline Total & & 96 & 100 & 409 \\
\hline \multicolumn{4}{|c|}{ Rata-rata Item } & 4,26 \\
\hline
\end{tabular}

Rata-rata variabel desire 2 sebesar 4,26 yaitu pada kategori "Sangat Efektif" dan dapat diartikan iklan produk @bangkayu.id pada media sosial Instagram sangat efektif dalam menimbulkan keinginan audiens setelah melihat tayangan iklan produk @bangkayu.id.

Tabel 9 : Variabel Desire 3

Informasi mengenai produk @bangkayu.id

\begin{tabular}{|c|c|c|c|c|}
\hline \multirow[b]{2}{*}{$\begin{array}{l}\text { Indikator } \\
\text { Penilaian }\end{array}$} & \multirow[b]{2}{*}{$\begin{array}{c}\text { Bobot } \\
\text { (wi) }\end{array}$} & \multicolumn{3}{|c|}{ Desire 3} \\
\hline & & $\begin{array}{c}\text { Frekuensi } \\
(\mathbf{F i})\end{array}$ & Presentase \% & $\begin{array}{c}\Sigma \\
\text { (wi.F) }\end{array}$ \\
\hline Sangat tidak Setuju & 1 & 2 & 2,1 & 2 \\
\hline Tidak Setuju & 2 & 3 & 3,1 & 6 \\
\hline Cukup Setuju & 3 & 4 & 4,2 & 12 \\
\hline Setuju & 4 & 62 & 64,6 & 248 \\
\hline Sangat Setuju & 5 & 25 & 26 & 125 \\
\hline Total & & 96 & 100 & 393 \\
\hline \multicolumn{4}{|c|}{ Rata-rata Item } & 4,09 \\
\hline
\end{tabular}

Rata-rata variabel desire 3 sebesar 4,09 yaitu pada kategori "Efektif" dan dapat diartikan iklan produk @bangkayu.id pada media sosial Instagram efektif dalam menumbuhkan keinginan menggunakan produk @bangkayu.id. Iklan menampilkan konsep sebaik mungkin untuk menarik perhatian konsumen, dengan maksud setelah melihat iklan audiens terpengaruh dan memiliki keinginan untuk menggunakan produk @bangkayu.id.

Tabulasi sederhana pada butir pertanyaan Desire 1,2,3 jawaban responden cenderung dengan jawaban pada atribut "Setuju" dan pada kategori efektif. Setelah ketiga pertanyaan Desire keseluruhan dijumlahkan langkah selanjutnya yaitu menghitung rata-rata dari keseluruhan tahap desire untuk mengetahui tingkat efektifnya.

Analisis rata-rata dari keseluruhan variabel interest 1, 2, 3. Dimaksudkan untuk mengetahui keefektifannya. Maka perhitungannya menggunaakan rumus sebagai berikut:

$$
x=\frac{\sum f i . w i}{\sum f i}
$$


Keterangan :

$\begin{array}{lll}\text { x } & : & \text { Rata-rata berbobot } \\ \text { fi } & : & \text { Frekuensi } \\ \text { wi } & : & \text { Bobot }\end{array}$

Nilai Rata - rata dari variabel Interest $1: 4,04$

Nilai Rata - rata dari variabel Interest $2: 4,26$

Nilai Rata - rata dari variabel Interest $3: 4,09$

Dengan demikian didapat hasil sebagai berikut:

$$
\frac{4,04+4,26+4,09}{3}=4,13
$$

Dari perhitungan tersebut nilai Desire (Keinginan) adalah sebesar 4,13 nilai ini berada pada rentang skala 3,40 - 4,19 yaitu "Efektif". Dapat disimpulkan bahwa pada tahap desire iklan produk @ bangkayu.id pada media sosial Instagram efektif membuat audiens merasa ingin membeli dan menggunakan produk @bangkayu.id.

\section{4) Action}

Tabel 10 : Variabel Action 1

Informasi mengenai produk @bangkayu.id

\begin{tabular}{|c|c|c|c|c|}
\hline \multirow{2}{*}{$\begin{array}{l}\text { Indikator } \\
\text { Penilaian }\end{array}$} & \multirow{2}{*}{$\begin{array}{c}\text { Bobot } \\
\text { (wi) }\end{array}$} & \multicolumn{3}{|c|}{ Action 1} \\
\hline & & $\begin{array}{l}\text { Frekuensi } \\
\text { (Fi) }\end{array}$ & Presentase \% & $\begin{array}{c}\Sigma \\
\text { (wi.F) }\end{array}$ \\
\hline Sangat tidak Setuju & 1 & 2 & 2,1 & 2 \\
\hline Tidak Setuju & 2 & 3 & 3,1 & 6 \\
\hline Cukup Setuju & 3 & 2 & 2,1 & 6 \\
\hline Setuju & 4 & 61 & 63,5 & 244 \\
\hline Sangat Setuju & 5 & 28 & 29,2 & 140 \\
\hline Total & & 96 & 100 & 398 \\
\hline \multicolumn{4}{|c|}{ Rata-rata Item } & 4,14 \\
\hline
\end{tabular}

Rata-rata variabel action 1 sebesar 4,14 yaitu pada kategori "Efektif" dan dapat diartikan iklan produk @bangkayu.id pada media sosial Instagram efektif dalam meyakinkan audiens untuk mengenal lebih jauh produk @bangkayu.id. Tahap action merupakan tahap akhir dalam iklan yaitu konsumen melakukan tindakan atau tidak. Sesuai dengan indikator yang ada pada tahap action yaitu keyakinan menggunakan produk, hal ini cukup sulit bagi pengiklan dan diperlukan strategi yang baik untuk memberitahukan kepada audiens bahwa produk yang ditawarkan berkualitas. 
Tabel 11 : Variabel Action 2

Informasi mengenai produk @bangkayu.id

\begin{tabular}{|c|c|c|c|c|}
\hline \multirow[b]{2}{*}{$\begin{array}{l}\text { Indikator } \\
\text { Penilaian }\end{array}$} & \multirow[b]{2}{*}{$\begin{array}{c}\text { Bobot } \\
\text { (wi) }\end{array}$} & \multicolumn{3}{|c|}{ Action 2} \\
\hline & & $\begin{array}{l}\text { Frekuensi } \\
\text { (Fi) }\end{array}$ & Presentase \% & $\underset{\text { (wi.F) }}{\Sigma}$ \\
\hline Sangat tidak Setuju & 1 & 2 & 2,1 & 2 \\
\hline Tidak Setuju & 2 & 3 & 3,1 & 6 \\
\hline Cukup Setuju & 3 & 10 & 10,4 & 30 \\
\hline Setuju & 4 & 54 & 56,3 & 216 \\
\hline Sangat Setuju & 5 & 27 & 28,1 & 135 \\
\hline Total & & 96 & 100 & 389 \\
\hline \multicolumn{4}{|c|}{ Rata-rata Item } & 4,05 \\
\hline
\end{tabular}

Source: Primary data processed, 2021

Rata-rata variabel action 2 sebesar 4,05 yaitu pada kategori "Efektif" dan dapat diartikan iklan produk @bangkayu.id pada media sosial Instagram efektif dalam menarik dan meyakinkan audiens untuk mengenal lebih jauh dan membeli produk @ bangkayu.id. Iklan yang baik tidak hanya dapat menarik perhatian audiens tetapi juga bisa mempengaruhi untuk melakukan tindakan tergantung bagaimana konsep iklan yang ditampilkan.

Tabel 12 : Variabel Action 3

Informasi mengenai produk @ bangkayu.id

\begin{tabular}{|c|c|c|c|c|}
\hline \multirow{2}{*}{$\begin{array}{l}\text { Indikator } \\
\text { Penilaian }\end{array}$} & \multirow{2}{*}{$\begin{array}{c}\text { Bobot } \\
\text { (wi) }\end{array}$} & \multicolumn{3}{|c|}{ Action 3} \\
\hline & & $\begin{array}{l}\text { Frekuensi } \\
\text { (Fi) }\end{array}$ & Presentase \% & $\underset{\text { (wi.F) }}{\Sigma}$ \\
\hline Sangat tidak Setuju & 1 & 2 & 2,1 & 2 \\
\hline Tidak Setuju & 2 & 3 & 3,1 & 6 \\
\hline Cukup Setuju & 3 & 7 & 7,3 & 21 \\
\hline Setuju & 4 & 59 & 61,5 & 236 \\
\hline Sangat Setuju & 5 & 25 & 26 & 125 \\
\hline Total & & 96 & 100 & 390 \\
\hline \multicolumn{4}{|c|}{ Rata-rata Item } & 4,06 \\
\hline
\end{tabular}

Source: Primary data processed, 2021

Rata-rata variabel action 3 sebesar 4,06 yaitu pada kategori "Efektif" dan dapat diartikan bahwa bahasa yang digunakan dalam iklan produk @bangkayu.id efektif dalam meyakinkan audiens untuk menggunakan produk @bangkayu.id. Dalam penyampaian pesan sebaiknya didhindari penggunaan bahasa yang kurang dipahami oleh segmentasi yang dituju. Ini ditujukan agar pesan iklan mudah dipahami ke telinga calon konsumen dan kemungkinan terjadinya salah tafsir atau persepsi dari khalayak terhadap pesan yang ingin disampaikan. Untuk produk yang ditujukan pada segmentasi yang beragam perlu memperhatikan hal itu secara hati-hati. penggunaan bahasa juga perlu diperhatikan karena berkaitan dengan persepsi konsumen dan keyakinan akan produk yang ditawarkan.

Tabulasi sederhana pada butir pertanyaan Desire 1,2,3 jawaban responden cenderung dengan jawaban pada atribut "Setuju" dan pada kategori efektif. Setelah ketiga pertanyaan Desire keseluruhan dijumlahkan langkah selanjutnya yaitu menghitung rata-rata dari keseluruhan tahap desire untuk mengetahui tingkat efektifnya. 
Analisis rata-rata dari keseluruhan variabel interest 1, 2, 3. Dimaksudkan untuk mengetahui keefektifannya. Maka perhitungannya menggunaakan rumus sebagai berikut:

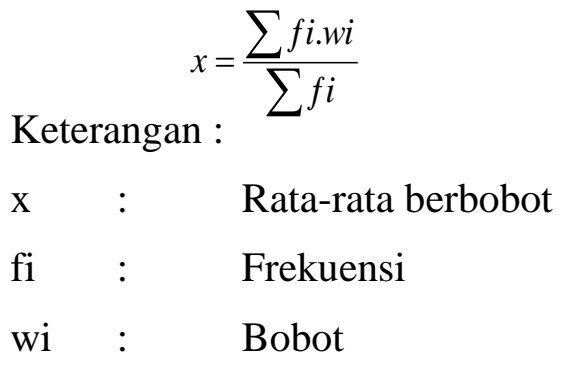

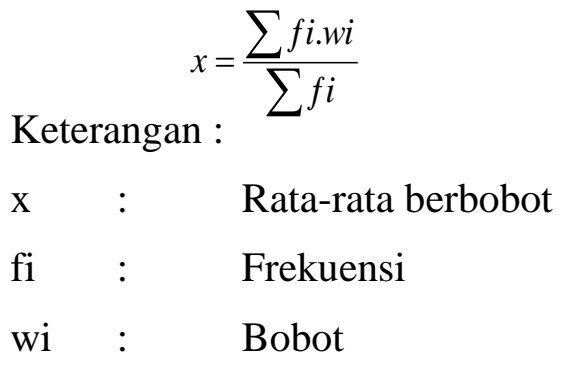

Nilai Rata - rata dari variabel Interest $1: 4,14$

Nilai Rata - rata dari variabel Interest $2: 4,05$

Nilai Rata - rata dari variabel Interest $3: 4,06$

Dengan demikian didapat hasil sebagai berikut:

$$
\frac{4,14+4,05+4,06}{3}=4,08
$$

Dari perhitungan tersebut nilai Desire (Keinginan) adalah sebesar 4,08 nilai ini berada pada rentang skala 3,40 - 4,20 yaitu "Efektif". Dapat disimpulkan bahwa tahapan akhir ini, iklan produk @bangkayu.id efektif dalam meyakinkan responden untuk melakukan (action) tindakan mengenal lebih jauh dan menggunakan produk, serta memutuskan untuk membeli produk @bangkayu.id.

\section{Pembahasan}

\section{Analisis Rata-Rata AIDA (Attention, Interest, Desire, Action)}

Setelah masing-masing variabel dalam AIDA (Attention, Interest, Desire, Action) diketahui jumalah rata-ratanya. Selanjutnya yaitu menghitung berdasarkan keseluruhan AIDA (Attention, Interest, Desire, Action) untuk mengetahui jumlah rata-rata akhir. Diolah dengan pendekatan rumus skor rata-rata:

\begin{tabular}{cccc}
\hline \multicolumn{3}{c}{ AIDA } & \\
\hline Attention & Interest & Desire & Action \\
\hline 4,00 & 4,04 & 4,13 & 4,08 \\
$($ Efektif $)$ & (Efektif) & (Efektif) & (Efektif) \\
& Total $=\frac{4,00+4,04+4,13+4,08}{4}=\frac{16,25}{4}=4,0625$ \\
& \multicolumn{4}{c}{ Rata- rata $=\mathbf{4 , 0 6}$}
\end{tabular}

Source: Primary data processed, 2021

Secara keseluruhan dari Konsep AIDA, maka iklan Produk @bangkayu.id berada pada rentang skala "Efektif" menarik respon audiens untuk membeli produknya. Berdasarkan jawaban responden, responden yakin untuk melakukan pembelian karena 
yakin terhadap produk @bangkayu.id setelah melihat visualisasi iklan dan mengetahui pesan yang di sampaikan iklan tersebut pada media sosial Instagram. Jadi kesimpulannya iklan produk @bangkayu.id efektif dalam meyakinkan konsumen hingga ke tahap action (tindakan pembelian).

\section{PENUTUP}

Iklan merupakan salah satu bentuk promosi yang paling banyak digunakan perusahaan dalam mempromosikan produknya. Dalam penelitian ini menunjukkan bahwa iklan produk @ bangkayu.id efektif dalam meyakinkan konsumen hingga ke tahap action (tindakan pembelian) dengan skor rata-rata AIDA berada pada 4,0625 dengan rentang skala 3,40-4,19 yaitu "Efektif".

Pada dasarnya hasil akhir dari aktivitas periklanan adalah untuk mendapatkan seseorang agar membeli suatu produk maupun jasa. Untuk menjangkau tujuan iklan dapat menggunakan konsep AIDA (attention), mempertahankan ketertarikan (interest), membangkitkan keinginan (desire), dan menggerakkan tindakan (action).

\section{DAFTAR PUSTAKA}

Ashley, C., \& Tuten, T. (2015). Creative strategies in social media marketing: An exploratory study of branded social content and consumer engagement. Psychology \& Marketing, 32(1), 15-27.

Atmoko D, B. (2012). Instagram handbook tips fotografi ponsel. Jakarta: Media Kita.

Badri, M. (2011). Corporate and marketing communication. Jakarta: Pusat Studi Komunikasi dan Bisnis Program Paca Sarjana Universitas Mercu Buana.

Best, R, J. (2012). Market-based management: strategies for growing customer value and profitability 6th ed. New Jersey: Prentice Hall.

Bilson, S. (2003). Memenangkan pasar dengan pemasaran efektif \& profitabel. Jakarta: Gramedia Pustaka Utama.

Buinac, E., \& Lundberg, J. (2015). Instagram as a Marketing Tool: A Case Study about how Companies Communicate their Brands on Social Media.

Cannon, J. P., W. D. Perault, and E. J. McCarthy. (2009). Pemasaran dasar: pendekatan manajerial global, edisi 16. Jakarta: Salemba Empat.

Charles L, W. et.al. (2001). Pemasaran edisi pertama. Jakarta: Salemba Empat.

Chikameirani dan Anna Fatchiya. (2017). Efektivitas website dan instagram sebagai sarana promosi kawasan wisata berbasis masyarakat. From ejournal.skpm.ipb.ac.id/index.php/jskpm/article/view/119.pdf.

Dailey, P, R. (2009). Social media: finding its way into your business strategy and culture, Burlington: Linkage.

Durianto, dkk. (2003). Invasi pasar dengan iklan yang efektif: strategi program, dan teknik pengukuran. Jakarta: Gramedia Pustaka Utama.

Fandy, T. (2001). Manajemen pemasaran dan analisa perilaku konsumen. Yogyakarta: $B P F E$. 
Gamble, M and Teri Kwal Gamble. (2005). Communication work 8th edition. New York: McGraw-Hill.

Guiltinan, J P. \& Gordon W. Paul. (1994). Strategi dan program manajemen pemasaran, edisi kedua. Jakarta: Erlangga.

Hermawan, A. (2012). Komunikasi pemasaran. Jakarta: Erlangga.

Indriarto, F. (2006). Studi mengenai faktor kekhawatiran dalam proses penyampaian pesan iklan. Jurnal Sains Pemasaran Indonesia, Vol. 5, No. 3, pp.243-268.

Jefkins, F. (1997). Periklanan. Jakarta: Erlangga.

Johar, D S, Srikandi Kumadji, \& M. Kholid Mawardi. (2015). Pengaruh AIDA (Attention, Interest, Desire, Action) terhadap efektivitas iklan online (Survei pada pembeli di toko online adorable project). Surabaya: Universitas Brawijaya.

Kennedy, J dan Dermawan Soemanagara. (2006). Marketing communication taktik dan strategi. Jakarta: Buana Ilmu Populer.

Kotler, P dan Gary Amstrong. (2002). Dasar-dasar Pemasaran jilid 1, alih bahasa Alexander Sindoro dan Benyamin Molan. Jakarta: Prenhalindo.

Kotler, P dan Gary Amstrong. (2008). Prinsip-prinsip pemasaran, jilid 1. Jakarta: Erlangga.

Kotler, P dan Keller. (2009). Manajemen pemasaran. Jakarta : Erlangga.

Kotler, P. (2003). Marketing management. 11th ed. Upper Saddle River. NJ: Prentice Hall Inc.

Linda, S. (2010). Social Commerce - E-Commerce in Social Media Context. Vol:4, No: 12. Accessed on May $17^{\text {th }}$, $2018 \quad$ From http://citeseerx.ist.psu.edu/viewdoc/download?doi=10.1.1.865.9668\&rep=rep1\&t ype $=$ pdf.

Lupiyoadi dan Hamdani. (2006). Manajemen pemasaran jasa edisi kedua. Jakarta: Penerbit Salemba Empat.

Manneh, M. (2017). The influence of social media on e-commerce: fast fashion multinational companies.

Priyono, A., Ijomah, W., \& Bititci, U. S. (2016). Disassembly for remanufacturing: A systematic literature review, new model development and future research needs. Journal of Industrial Engineering and Management (JIEM), 9(4), 899-932.

Sugiyono. (2009). Metode penelitian kuantitatif, kualitatif, R \& D. Bandung: Alfabeta.

Syifa, N. D dan Bethani S. (2017). Analisis efektivitas promosi melalui media sosial instagram pada PT. NIION Indonesia Utama pada tahun 2017. Bandung: Universitas Telkom.

Tjiptono. F. (1997). Prinsip-prinsip total quality service. Yogyakarta: Penerbit Andi.

Tjiptono. F. and Gregorius Chandra. (2007). Service, quality satisfaction. Yogyakarta: Andi Ofset.

Wijaya, L A. (2015). Strategi komunikasi pemasaran buku tulis siswa melalui twitter dalam pembentukan brand awareness. Yogyakarta: Universitas Atma Jaya. 